\title{
Cropping History Effects on Pathogen Suppressive and Signaling Dynamics in Streptomyces Communities
}

\author{
Patricia Vaz Jauri, ${ }^{\dagger}$ Instituto Nacional de Investigación Agropecuaria, Plataforma de Bioinsumos, Rincón del \\ Colorado, Canelones, Uruguay 90200, and Instituto de Investigaciones Biologicas Clemente Estable, Biología \\ Molecular y Genética Microbianas, Avda. Italia 3318, Montevideo 11600, Uruguay; Nora Altier, Instituto Nacional de \\ Investigación Agropecuaria, Proteccion Vegetal, Las Brujas, Canelones, Uruguay; Carlos A. Pérez, Universidad de \\ la Republica, Proteccion Vegetal, Ruta 3, km 363, Paysandu, Paysandu 6000, Uruguay; and Linda Kinkel, \\ University of Minnesota, Plant Pathology, 495 Borlaug Hall, 1991 Upper Buford Circle, St. Paul, MN 55108
}

Accepted for publication 17 December 2017.

\section{ABSTRACT}

Diseases remain a yield-limiting factor for crops despite the availability of control measures for many pathogens. Indigenous soil microorganisms can suppress some plant pathogens, yet there is little systematic information on the effects of cropping systems on disease-suppressive populations in soil. Streptomyces have been associated with suppression of plant diseases in several naturally occurring disease-suppressive soils. Pathogensuppressive activity of Streptomyces communities is correlated with higher bacterial densities and with inhibitory phenotypes, driven by competition among indigenous soil bacteria. We sought to characterize relationships between cropping practices and pathogen suppression among soil Streptomyces. We evaluated bacterial and Streptomyces densities and inhibitory activities in soils from a long-term crop rotation experiment. Signaling interactions that altered inhibitory phenotypes among sympatric populations were also evaluated for a subset of samples. Soils from longer rotations, which had a higher number of plant species over time, had larger bacterial and Streptomyces densities, and more inhibitors than soils from shorter rotations. In addition, signaling occurred more frequently among isolates from higherdensity communities. Our work shows that bacterial density, pathogen suppression and signaling are interrelated and are affected by crop rotation, suggesting the potential for management to optimize suppressive populations.
Diseases of crop plants caused by viruses, viroids, bacteria, fungi, nematodes, and insects can significantly reduce crop yields (Gordon and Leveau 2010). In order to limit the spread and damage of crop diseases, diverse control measures have been deployed, including resistant varieties and the use of crop rotations and pesticides (Lew et al. 2012; Panuwet et al. 2012). However, despite these options, disease management remains a persistent challenge.

Antagonistic soil microorganisms have the potential to protect plants from pathogens, and have been used as inoculants to control diseases (Janmaat 2007; Jones et al. 2016; Lumsden and Knauss 2007; Perneel et al. 2008). Suppressive soils, which are soils in which a pathogen may persist, but causes little or no damage to susceptible crops, offer an alternative for managing soilborne pathogens (Cook

${ }^{\dagger}$ Corresponding author: P. Vaz Jauri; E-mail: pvaz@iibce.edu.uy

Funding for P. Vaz Jauri was provided by the University of Minnesota.

*The $e$-Xtra logo stands for "electronic extra" and indicates that three supplementary figures and two supplementary tables are published online.

(c) 2018 The American Phytopathological Society
2007; Keel et al. 1996; Landa et al. 2002; Liu et al. 1995). Disease suppression in such soils is usually associated with the presence of microorganisms that limit the survival, growth, or infection of plant pathogens (Kinkel et al. 2011, 2012; Mendes et al. 2011). The biochemical mechanisms through which disease is reduced in suppressive soils are varied and include triggering of induced systemic resistance in the host plant (Larkin et al. 1996; Mandeel and Baker 1991; van Loon et al. 1998), resource competition (Cugudda and Garibaldi 1981; Larkin et al. 1996), antibiotic-based inhibition (Keel et al. 1992, 1996), and fungal and oomycete cell wall-degrading enzyme production (Hjort et al. 2010).

Bacterial community composition, richness, and diversity in the phytobiome are influenced by a complex array of biotic and abiotic factors (Andrew et al. 2012; Salles et al. 2004; Schmalenberger and Tebbe 2002; Shange et al. 2012). Soil type (Araújo da Silva et al. 2003; Birkhofer et al. 2012; Lauber et al. 2008), nutrient availability (Schlatter et al. 2009; Veresoglou et al. 2012), plant host (Bakker et al. 2010; Garbeva and van Veen 2004), and management practices (Azziz et al. 2012; Ceja-Navarro et al. 2010; Larkin et al. 2010) can significantly influence bacterial communities in soil. In cropped soils, bacterial richness and diversity are higher in the absence of tillage 
and when residue is retained in-field (Ceja-Navarro et al. 2010). Considering specifically pathogen suppression, agronomic practices to favor indigenous pathogen-suppressive microbial populations have been widely investigated (Alguacil et al. 2012; Allan et al. 2015; Essarioui et al. 2017; Mazzola 2007; Pérez et al. 2007; Ryan et al. 2009; Sakuma et al. 2011; Tamm et al. 2010; van Bruggen et al. 2015; Wiggins and Kinkel 2005a, b). However, results have been variable among systems, and the effects of phytobiome management on the antagonistic activities of the soil microbiome remain poorly understood.

Streptomyces (class Actinobacteria) is a gram-positive bacterial genus comprised of over 500 species that are ubiquitous both in soil and aquatic habitats (Bailey 2009; Kinkel et al. 2012; Vaz Jauri et al. 2016). Organisms of this genus are prolific antibiotic producers, which is hypothesized to be a primary basis for their pathogensuppressive capacity in soil (Bressan 2003; Kinkel et al. 2012; Wiggins and Kinkel 2005a), and are common components of phytobiomes. Communities of Actinobacteria have been associated with disease suppression in soils (Becker et al. 1997; Millard and Taylor 1927) and have also been shown to shift with management practices (Cretoiu et al. 2013; Kinkel et al. 2012; Mendes et al. 2011; Rosenzweig et al. 2012; Shange et al. 2012). Long-term monoculture has been hypothesized to select for pathogen-suppressive Streptomyces populations by inducing a nutrient-mediated antibiotic arms race within the soil microbiome (Kinkel et al. 2011, 2012). However, patterns of variation in pathogen-suppressive Streptomyces populations in relation to crop management practices or soil nutrient characteristic remain poorly understood.

Antibiotic production in Streptomyces is costly and highly regulated (Bibb 2005; Liu et al. 2013; Zhu et al. 2014). Several signaling molecules have been found to induce antibiotic production (Bunet et al. 2008; D'Alia et al. 2010; Gottelt et al. 2012; O'Rourke et al. 2009; Pulsawat et al. 2009; Xu et al. 2017). These molecules may participate in the modulation of interspecies interactions, or interspecies signaling, mediating interactions that range from cooperative to exploitative (Chandler et al. 2012; Hosni et al. 2011; Keller and Surette 2006). Signaling interactions that alter inhibition vary in frequency and effect among communities, and can vary with the genetic background of the coexisting isolates as well as other traits that are relevant for competition, such as nutrient utilization and antibiotic production (Vaz Jauri and Kinkel 2014). Furthermore, interspecies signaling interactions within the phytobiome have the capacity to fundamentally alter the expression of antibiotic biosynthetic genes within the soil microbial community, adding an additional layer of complexity to predicting/understanding the pathogensuppressive capacity of soil microbiomes. However, there has been little study of the frequency of microbial interspecies signaling interactions in agricultural soils, and the extent to which signaling interactions vary in response to distinct cropping histories is completely unexplored.

Here we explore the relationships between cropping history, pathogen suppression, and signaling within soil microbial communities under different cropping systems. Specifically, we characterize bacterial and Streptomyces densities, antagonistic and signaling activities of Streptomyces, and soil abiotic characteristics in relation to cropping systems varying in the length and number of species in the rotation within a long-term study in Uruguay. We hypothesize that the frequency and intensity of pathogen-suppressive capacities of Streptomyces populations will vary among cropping systems, and that this variation will be significantly associated with soil chemical characteristics. In addition, we hypothesize that sympatric interspecies signaling dynamics will vary among populations from different cropping systems. This work sheds light on the complex connections between crop management, soil chemistry, and microbial phenotypes critical to generating and sustaining pathogen-suppressive capacity within phytobiomes, and provides a first assessment of signaling phenotypes within agricultural cropping systems.

\section{MATERIALS AND METHODS}

We evaluated bacterial and Streptomyces densities, pathogen suppressive activity, and chemical characteristics of soils with different cropping histories from a no-till rotation experiment. In addition, signaling interactions that alter inhibition among sympatric pairwise interactions were determined for a subset of plots.

Soil sampling. Soil samples were collected from a no-till rotation experiment located at Plot $36\left(32^{\circ} 21^{\prime} 58^{\prime \prime} \mathrm{S}\right.$; $\left.58^{\circ} 03^{\prime} 56^{\prime \prime} \mathrm{W}\right)$ at the Dr. Mario A. Cassinoni Experimental Station (http://www.eemac.edu. uy/index.php/p-resentacion/localizacion) in Paysandú, Uruguay. The experiment was established in 1999 and has 10 treatments in four cropping sequences with varying rotation lengths (Table 1) in a randomized complete block design with three replicates. All crops

TABLE 1

Description of treatments used in this study ${ }^{a}$

\begin{tabular}{ccll}
\hline Treatment & Rotation length & Plant host (at sampling) & Rotation sequence \\
\hline 1Soy* & 1-year & Soybean & Wheat, soybean \\
\hline 2Sun & 2-year & Sunflower & Barley, sunflower, wheat, soybean \\
\hline 2Soy & 2-year & Soybean & Barley, sunflower, wheat, soybean \\
\hline 3Sor & 3-year & Sorghum & Barley, sorghum, oat, maize, wheat, soybean \\
\hline 3Mai & 3-year & Maize & Barley, sorghum, oat, maize, wheat, soybean \\
\hline 3Soy & 3-year & Soybean & Barley, sorghum, oat, maize, wheat, soybean \\
\hline 4Sun* & 4-year & Sunflower & Barley, sunflower, oat/lotus, lotus, wheat, soybean \\
\hline 4Lot1 & 4-year & Lotus & Barley, sunflower, oat/lotus, lotus, wheat, soybean \\
\hline 4Lot2 & 4-year & Lotus & Barley, sunflower, oat/lotus, lotus, wheat, soybean \\
\hline 4Soy & 4-year & Soybean & Barley, sunflower, oat/lotus, lotus, wheat, soybean \\
\hline NC.W & - & Woodland & - \\
\hline NC.P & - & Prairie & - \\
\hline
\end{tabular}

a All rotation soils were part of a long-term rotation experiment with three blocks, each hosting all 10 treatments randomly distributed in space. Thus, for each treatment there were three composite samples $(n=36) .{ }^{*}$ Indicates plots from block III carrying these treatments were selected for signaling tests. 
of all rotations are grown each year; thus, there is one treatment in the 1-year rotation, two treatments in the 2-year rotation, three treatments in the 3-year rotation, and four treatments in the 4-year rotation. The plots have not received any fungicides since the beginning of the experiment and are fertilized according to the established crop. Samples were collected from every plot in March 2012, at the end of the southern summer, while the summer crops were still standing. Ten soil cores $(2.5 \times 10 \mathrm{~cm})$ were collected from five randomly selected locations within the central rows of each plot. Soil cores from each plot were pooled in a bulk sample for further analyses. In addition, small cores $(1 \times 10 \mathrm{~cm})$ were collected at three of the five locations within each plot and were kept separate for Streptomyces isolation and signaling assays.

Samples from noncropped soils were collected in a similar fashion from a nearby noncultivated woodland (NC.W) and a noncultivated prairie adjacent to the cropped plots (NC.P). All soil samples were kept at $4^{\circ} \mathrm{C}$ until processed. Soil samples were tested for chemical properties using standard methods at the University of Minnesota Research Analytical Labs (http://soiltest.cfans.umn.edu/).

Characterization of inhibition activity and microbial densities. Pathogen inhibitory activity in each community was evaluated following a modified version of the Herr's assay (Pérez et al. 2007). Briefly, from each sample, soil was left to dry overnight at room temperature and approximately $5 \mathrm{~g}$ of soil was suspended in $50 \mathrm{ml}$ of sterile deionized water and shaken at $175 \mathrm{rpm}$ for $1 \mathrm{~h}$ at $4^{\circ} \mathrm{C}$. Serial dilutions were made into sterile deionized water and $100 \mu \mathrm{l}$ was plated onto petri dishes containing $15 \mathrm{ml}$ of starch casein agar (SCA) (Becker and Kinkel 1999). Plates were subsequently overlaid with a thin layer $(5 \mathrm{ml})$ of SCA and incubated at $28^{\circ} \mathrm{C}$. After 3 days, bacteria and Streptomyces colonies were counted. Subsequently, $10 \mathrm{ml}$ of SCA was added to each plate and, after drying, one of two target Streptomyces (4-21 or 1324-2) (Davelos et al. 2004) was spread from a concentrated spore suspension $\left(\approx 5 \times 10^{8}\right.$ spores $\left./ \mathrm{ml}\right)$ onto every plate ( $n=3$ replicates per isolate pair). The two target isolates have been shown previously to vary in sensitivity to antibiotics (Davelos et al. 2004), and inhibition to these targets is indicative of pathogen suppressive activity (Wiggins and Kinkel 2005a). Plates were incubated at $28^{\circ} \mathrm{C}$ for 3 days, at which time the number of inhibitory Streptomyces was determined on each plate. For every inhibitor, the average of two perpendicular measurements of the radius of each inhibition zone was measured. Thus, densities of general bacteria, Streptomyces, and inhibitors against both targets were counted and mean zones of inhibition for each target were determined.

Evaluation of sympatric Streptomyces signaling interactions. Three plots from a single block of the experiment were selected to characterize sympatric Streptomyces for signaling assays based on principal component analysis of all the biological data collected in order to capture a range of bacterial, Streptomyces, and inhibitor densities, as well as average inhibition zone size (Supplementary Table S1). The selected plots were as follows: one on a 1-year rotation, cropped to soybean (1Soy), another from a 4-year rotation, cropped to sunflower (4Sun), and one from a 4-year rotation, cropped to soybean (4Soy). From each of these plots, 10 sympatric isolates (from a single small soil core) were randomly selected from dilution plates. Briefly, soil samples were suspended and diluted in sterile deionized water, plated on oatmeal agar (oatmeal at $20 \mathrm{~g} /$ liter, casamino acids at $1 \mathrm{~g} / \mathrm{liter}$, and agar at $15 \mathrm{~g} / \mathrm{liter}$ ), and incubated at $28^{\circ} \mathrm{C}$ for 3 to 7 days. Colonies displaying characteristic Streptomyces morphology were randomly selected and subcultured on oatmeal agar and ISP2 (Shirling and Gottlieb 1966). All isolates were kept as spore suspensions in $20 \%$ glycerol at -20 and $-80^{\circ} \mathrm{C}$. In total, 30 Streptomyces isolates from the three distinct communities were evaluated.

Signaling was defined as an event in which one Streptomyces isolate significantly altered the inhibition phenotype of another isolate. Interactions were evaluated among all pairwise isolate combinations within each community $(n=10$ isolates $\times 9$ partners $\times$ 3 communities $=270$ interactions). Assays were carried out as described previously (Vaz Jauri and Kinkel 2014), with some modifications. Briefly, Streptomyces isolates were inoculated in pairs $1 \mathrm{~cm}$ apart on plates containing $15 \mathrm{ml}$ of ISP2 medium. Four replicates of each pair were inoculated per plate. Control plates were inoculated with four replicates of each isolate grown individually. Isolates were inoculated as $4 \mu \mathrm{l}$ drops from spore suspensions to a final number of $\approx 5 \times 10^{7}$ spores and plates were incubated at $28^{\circ} \mathrm{C}$. After 3 days, $10 \mathrm{ml}$ of ISP2 was overlaid on top of the colonies and was allowed to dry. After drying, a target Streptomyces that had previously been selected to be sensitive to inhibition by the test isolate was spread from a concentrated spore suspension $\left(\approx 5 \times 10^{8}\right.$ spores $\left./ \mathrm{ml}\right)$ onto the medium. Plates were incubated again at $28^{\circ} \mathrm{C}$. After 3 days, inhibition zones were measured on the target Streptomyces lawns. Two perpendicular measurements were made per zone from the edge of the test Streptomyces colony to the outer edge of the inhibition zone (zone radius), away from the paired isolate, and their average was used for statistical analyses. Inhibition zones of paired Streptomyces were compared with zones generated by each test Streptomyces isolate grown on ISP2 plates alone (controls). The effect of a paired isolate was evaluated by testing the significance and direction (increase or decrease of inhibition) of differences between the inhibition zones of isolates in the presence and the absence of a paired isolate. Some isolate pairs were tested with two different target overlays, due to inherent differences in their antibiotic activity spectrum. As a result, cases in which an isolate did not inhibit a target in its control test (growing alone) but inhibited the same target when coinoculated were also recorded.

Analyses. Correlation analyses, one-way analysis of variance, and Tukey's least significant differences were carried out using Matlab Statistics Toolbox (MATLAB version 7.8.0. Natick, MA: The MathWorks Inc, 2009). Contrast analyses were carried out using R. Differences in the frequency in signaling and frequency of increases or decreases of inhibition were analyzed using the $\chi^{2}$ test (http://www. quantpsy.org/chisq/chisq.htm). Differences in signaling intensities were tested using the Infostat (Di Rienzo et al. 2011) glm procedure considering variances nonhomogeneous among isolates.

\section{RESULTS}

Cropping system variations in bacterial and Streptomyces densities. Soils with different cropping histories varied significantly in bacterial and Streptomyces densities, differing up to twofold among soils (Figs. 1A and 2A, respectively). Bacterial density differed significantly between the noncropped prairie soil (NC.P) and three cropped soils from the 3- and 4-year rotations (3Mai, 4Sun, and 4Lot2). Of those, the two with the highest bacterial densities (3Mai, 4Sun) also had significantly higher Streptomyces densities than 2Soy, which had the lowest Streptomyces density. Overall, bacterial and Streptomyces densities were positively correlated (Pearson's $\mathrm{r}=0.720, P<0.0001$ ).

Soils with different rotation lengths also varied significantly in bacterial and Streptomyces densities (Figs. 1B and 2B, respectively). Contrast analyses revealed that soils from longer rotations harbored higher bacterial densities than soils from shorter rotations, and noncropped soils had intermediate bacterial densities, although not significantly different from the 1- and 2-year rotations. In contrast to bacterial densities, Streptomyces densities in soils on 1-year rotations were significantly higher than those of the 2-year rotations, and not different from densities on 3- and 4-year rotations. In soils with no cropping, both bacterial and Streptomyces densities were significantly lower than in 3- and 4-year rotations. 
Plots with different host plants at the time of sampling also varied significantly in bacterial and Streptomyces densities (Figs. 1C and 2C, respectively). Plots planted most recently with maize harbored significantly higher bacterial densities than plots with any other plant species. Plots planted most recently with sorghum, sunflower and lotus had bacterial densities comparable to those in noncropped soils, and soils planted with soybean had, on average, significantly lower densities of bacteria than all other soils. Streptomyces densities among noncropped and agricultural soils with different crops were similar, except for those planted with maize, which had Streptomyces densities 50\% higher than noncropped and lotus-cropped soils.

Contrast analyses were also performed on bacterial and Streptomyces densities based on the number of different plant species grown during the preceding 4 years. Rotations of 3 - and 4-year lengths had the same number of plant species during the 4-year period (Table 1), and were thus combined for this analysis. Bacterial densities increased with increasing plant diversity, with six-species plots having significantly higher bacterial densities than 2- or 4-species plots (Fig. 1D). However, in contrast to total bacteria, Streptomyces populations did not increase consistently with the number of species planted in the preceding 4-year period. Soils planted to two species over the preceding 4 years had more than $45 \%$ higher Streptomyces densities than soils planted to four species, and Streptomyces densities were highest in soils with six plant species (Fig. 2D). Thus, although highly correlated, bacterial and Streptomyces densities did not show the same patterns among plots with different numbers of plant species.

Cropping systems variations in pathogen suppression traits. The average density of inhibitors against the two targets (Streptomyces spp. 4-21 and 1324-2) was significantly different among soils with different cropping histories (Fig. 3A). Soils from 4-year rotations cropped to sunflower (4Sun) harbored the highest densities of inhibitors, which were significantly higher than in the noncropped soils and three of the cropped soils.

The density of inhibitors varied among rotations of different length (Fig. 3B). Noncropped soils had the lowest density of inhibitors, but densities were not significantly different from those in 1-year rotations. Cropped soils having longer rotation lengths had significantly larger inhibitor densities, and soils having 2-, 3-, or 4year rotations supported similar inhibitor densities.

Contrast analyses of average inhibitor density also revealed differences among soils with different plant species (Fig. 3C). Noncropped soils had significantly lower densities of inhibitors than cropped soils and among cropped soils, those with sunflower had significantly higher densities of inhibitors than other soils.

Among plots with different number of plant species, only differences between communities from two and four crops every 4-year period could be detected, with soils with four crops harboring $54 \%$ higher densities of inhibitors $(P=0.034$; Fig. 3D). Furthermore, no significant differences in zone sizes were found among soils from different treatments, with zone sizes on both targets ranging from 0.5 to $9.0 \mathrm{~cm}$ and an average of $2.4 \mathrm{~cm}$ (Supplementary Fig. S1).

Among soils, the density of inhibitors against the two targets was positively correlated (Spearman's rho $=0.3430, P<0.0471$ ). Thus, soil communities that were good at inhibiting one target were generally good at inhibiting the other target. Furthermore, the density of bacteria was significantly correlated with the average density of inhibitors and the average intensity of inhibition toward
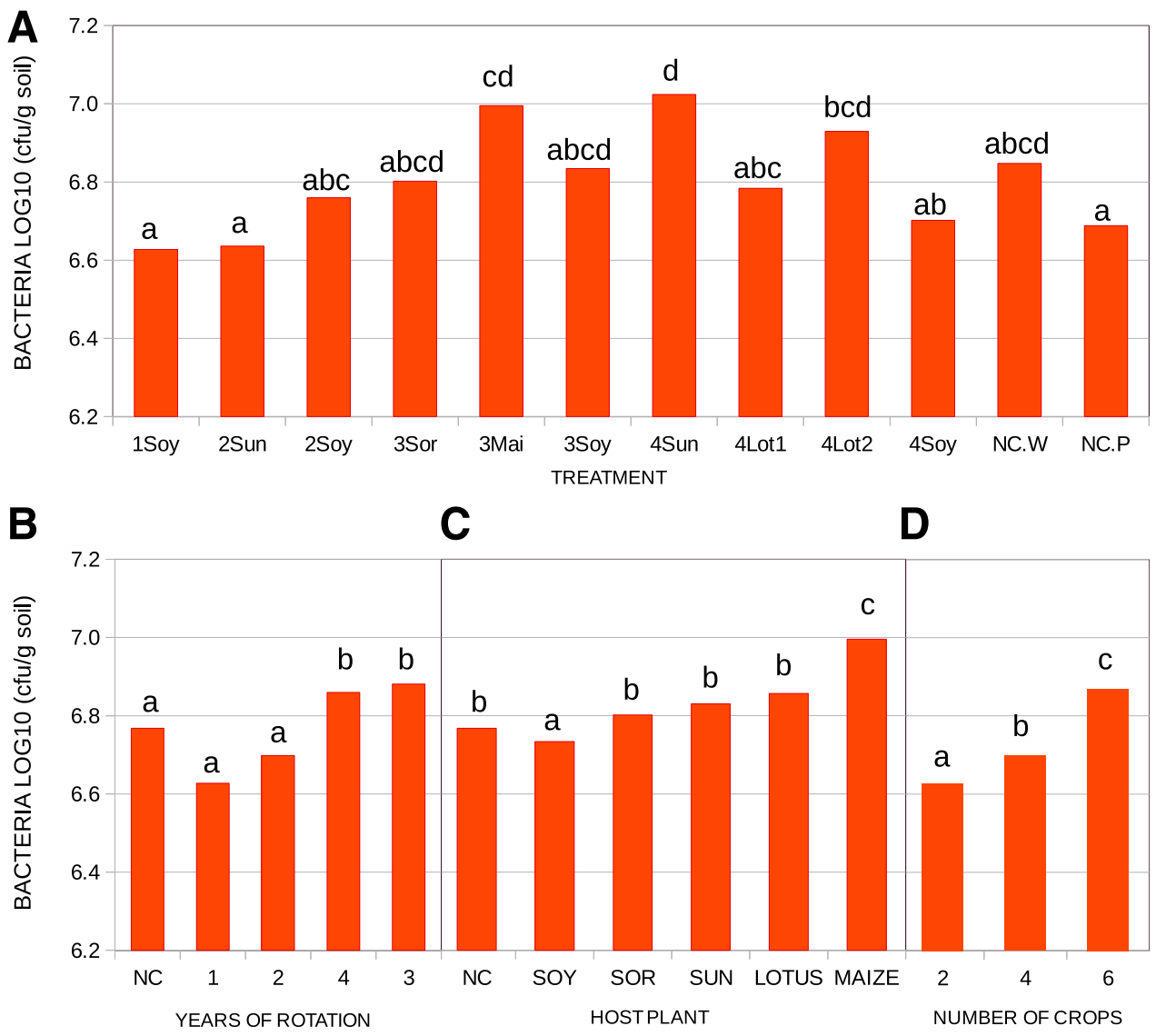

Fig. 1. Total bacterial density varied among soils. A, Soils under different treatments varied significantly in bacterial density (analysis of variance, $\mathrm{F}[11,204]=6.748, P<0.00001$; Tukey's honest significant difference $P<0.05)$. Contrast analyses revealed significant differences $(P<0.05)$ among soils with different $\mathbf{B}$, rotation length, $\mathbf{C}$, host plant, and $\mathbf{D}$, number of crops. Different letters within each box represent significant differences. 
both targets (Spearman's rho $=0.3967$ and $0.3725 ; P=0.0202$ and 0.0300 , respectively) and soils with high average density of inhibitors had higher proportions of inhibitors among their Streptomyces populations (Fig. 4). Correlation between the density of inhibitors and the average size of inhibition zones among soils was not significant for target 1324-2, but marginally significant for target 4-21 (Supplementary Fig. S2). Thus, in soils with higher densities of Streptomyces that were inhibitory against 4-21, inhibitors were more effective than in soils with lower densities of inhibitors.

Soil chemical properties. Soils had a wide range of nitrate, organic matter, phosphorous, potassium and $\mathrm{pH}$ levels (Supplementary Table S2). Nitrate varied significantly among soils with different cropping histories, ranging from 17 to $90 \mathrm{ppm}$, with an average of $33.1 \mathrm{ppm}$. Soils from noncropped woodland, in Uruguay are composed of mostly legume species that are symbiotic with nitrogen-fixing symbionts (Platero et al. 2016; Taulé et al. 2012), and had more than twice the nitrogen than soils from 1-, 2-, and 3year rotations. Soils in 4-year rotations, which had 2 years of lotus (another legume with nitrogen-fixing symbionts) with no grazing, also had significantly higher nitrate than soils in the other rotations (Supplementary Fig. S3). Furthermore, among cropped soils, those planted with lotus at the time of sampling had significantly higher nitrate than soils with all other crops.

Despite the very high nitrate and low inhibitory densities in noncropped soils, over all samples (which are dominated by cropped plots), nitrate in soil was positively correlated with density of bacteria and with both the density and inhibitory intensity of
Streptomyces toward target Streptomyces 4-21 (Pearson's $\mathrm{r}=$ 0.3453 and $0.5410 ; P=0.0455$ and 0.0001 ; Spearman's rho $=$ $0.3994 ; P=0.0193$, respectively). Thus, soils with higher nitrate content supported higher bacterial and inhibitor densities and better inhibitors. No significant differences were observed in organic matter and soluble potassium content among soils with different cropping histories. However, organic matter in soils was positively correlated with biotic properties, such as bacterial and 4-21 inhibitor densities (Pearson's $\mathrm{r}=0.3782$ and $0.5544 ; P=0.0274$ and 0.0007 , respectively). Furthermore, both organic matter and soluble potassium were significantly positively correlated with inhibition zone sizes against target Streptomyces 1324-2 (Spearman's rho $=0.5604$ and $0.5074, P=0.0006$ and 0.0022 , respectively). In addition, $\mathrm{pH}$ did not vary significantly among soils from different treatments, but was positively correlated with the average density of inhibitors (Spearman's rho $=0.3540 ; P=0.0400$ ).

Signaling phenotypes in three distinct communities. Changes in inhibitory phenotypes of an individual Streptomyces population in the presence of a second isolate were common, occurring in $56.4 \%$ of all pairwise sympatric interactions. The frequency of sympatric signaling was positively correlated with the average intensity of inhibition and density of inhibitors of each community against targets Streptomyces spp. 4-21 and 1324-2, suggesting that signaling that alters inhibition may be more important in highly antagonistic communities (Fig. 5A). The community from the plot planted to soybean on a 4-year rotation (4Soy) had a significantly higher frequency of signaling interactions than the community from the 1-year rotation (Fig. 5A). The community from plot 4Sun,
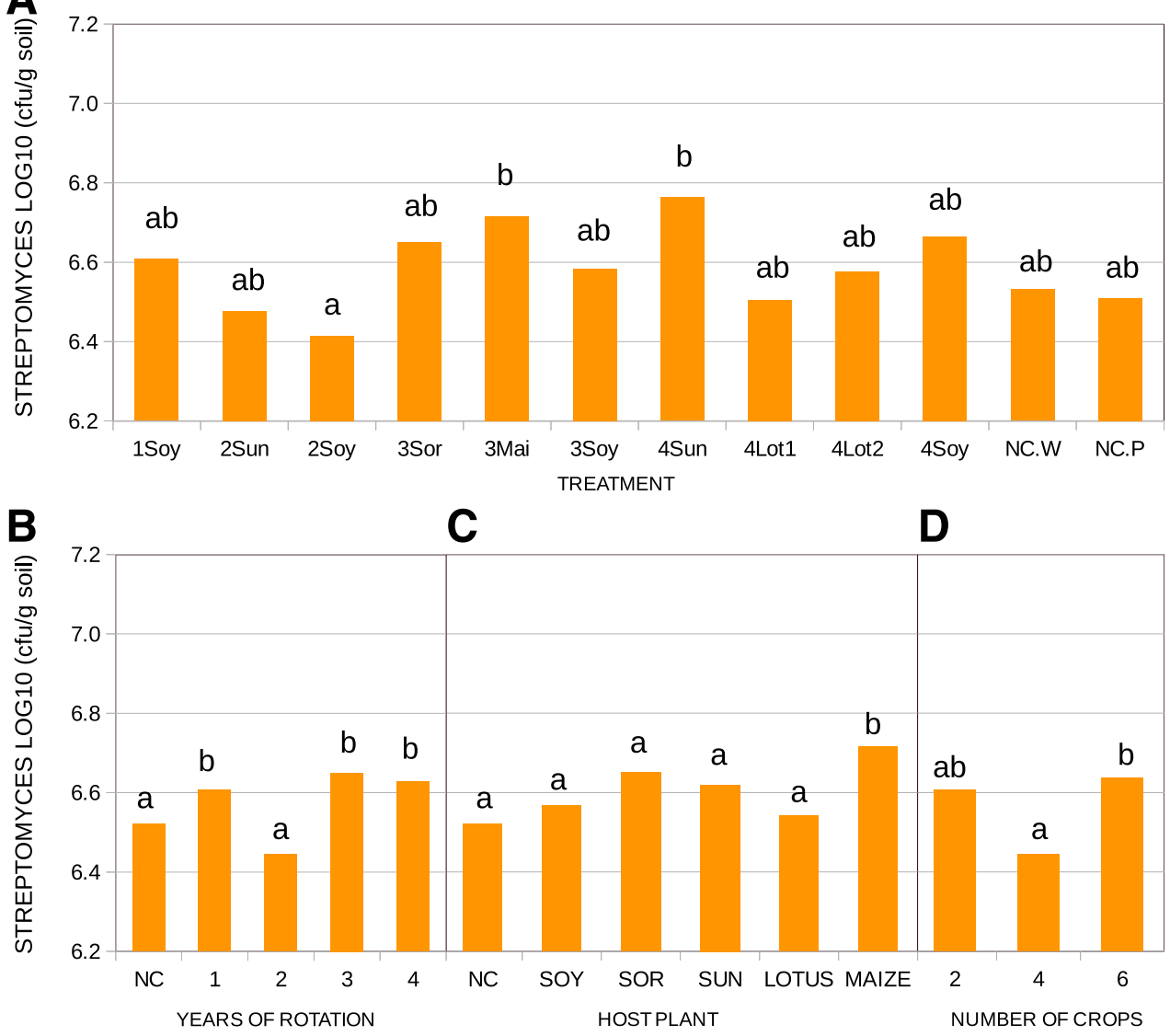

Fig. 2. Total Streptomyces spp. density varied among soils. A, Soils under different treatments varied significantly in Streptomyces spp. density (analysis of variance, $\mathrm{F}[11,204]=2.699, P=0.003$; Tukey's honest significant difference $P<0.05)$. Contrast analyses revealed significant differences $(P<0.05)$ among soils with different $\mathbf{B}$, rotation length, $\mathbf{C}$, host plant, and $\mathbf{D}$, number of crops. Different letters within each box represent significant differences. 
which was also from a 4-year rotation, but was cropped to sunflower rather than soybean, had intermediate levels of signaling and was not significantly different from the other two in the frequency of signaling interactions.

Both increases and decreases in inhibition were observed in response to a partner. Of the total shifts in inhibition, approximately $51 \%$ were increases. Communities varied in the proportion of increases and decreases in inhibition, though differences were not significant. However, differences in the intensity of changes were significantly different among communities both for increases and decreases in inhibition (Fig. 5B). Isolates from plot 1 Soy had the weakest responses in both directions compared with the other two plots, and isolates from the plot 4Sun had the strongest responses. Thus, isolates from the community with the lowest frequency of signaling, also showed the weakest responses to signaling. Differences between communities obtained from soils with different
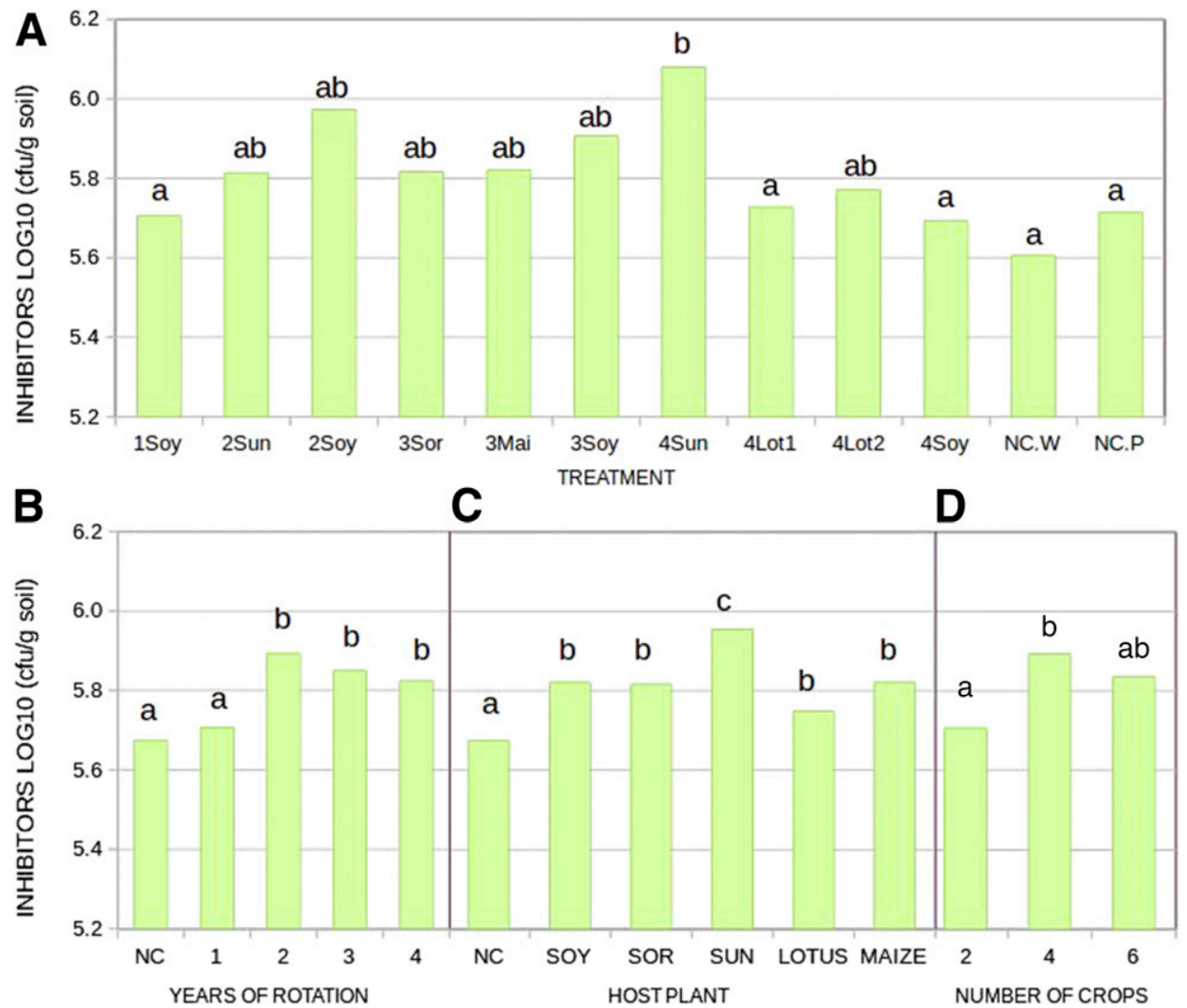

Fig. 3. Average inhibitor density varied among soils. A, Soils under different treatments varied significantly in average inhibitor density (analysis of variance, $\mathrm{F}[11,178]=3.347, P=0.0003$; Tukey's honest significant difference $P<0.05)$. Contrast analyses revealed significant differences $(P<0.05)$ among soils with different $\mathbf{B}$, rotation length, $\mathbf{C}$, host plant, and $\mathbf{D}$, number of crops. Different letters within each box represent significant differences.

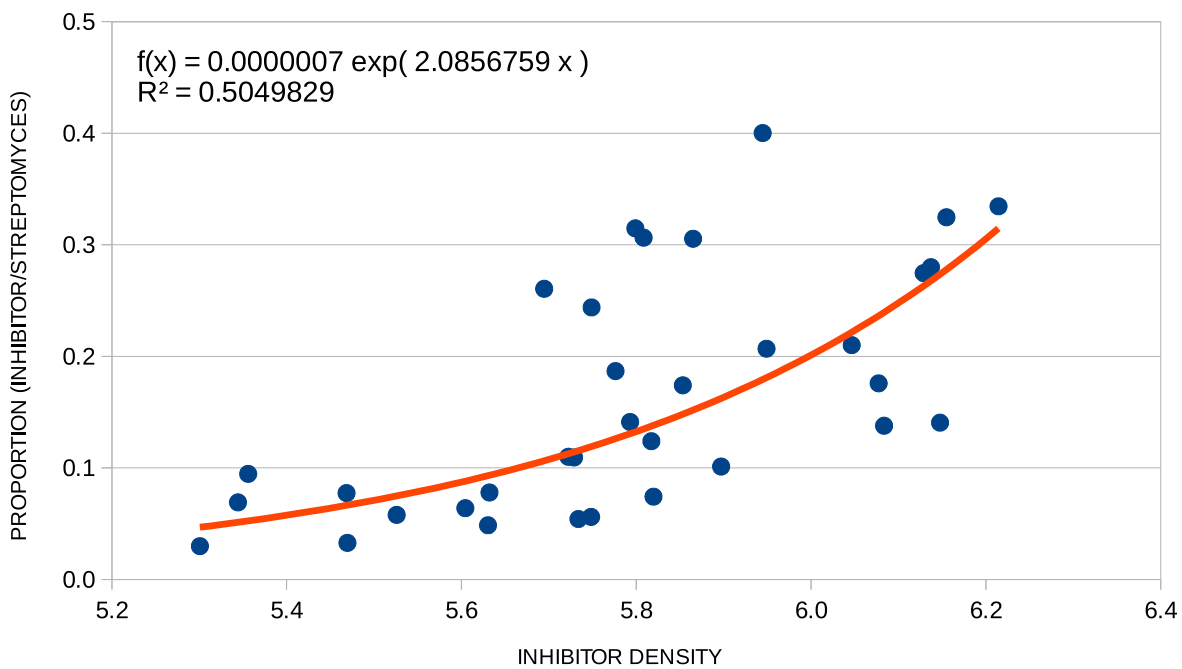

Fig. 4. Proportion of inhibitors on total Streptomyces spp. varied with average inhibitor density. Proportion of inhibitors on total Streptomyces spp. varied significantly among treatments and are higher in soils with larger inhibitor densities (Pearson's $r=0.9384, P<0.0001$ ). 
plant hosts, number of years of rotation, or treatment were not carried out due to the limited number of replications.

\section{DISCUSSION}

Consistent with previous work (Ceja-Navarro et al. 2010; Pérez et al. 2007; Xuan et al. 2011), we found that bacterial populations vary significantly with agricultural management practices. The number of years in a rotation, current or most recent plant species, and the number of plant species in each rotation were all associated with significant differences in bacterial density. Soils with different cropping histories also differed in Streptomyces density, consistent with previous studies (Ceja-Navarro et al. 2010; Pérez et al. 2007; Xuan et al. 2011). In this work, we have estimated shifts in total bacteria through culture-based methods. These methods recover only a fraction of total bacterial populations, and thus represent only a partial picture of the soil bacterial biome. However, by using consistent methods across a wide array of soil samples, differences in culturable bacteria in response to cropping are clear.

In this study, rotation length and the number of plant species in the previous 4 years were nonindependent: the 3- and 4-year
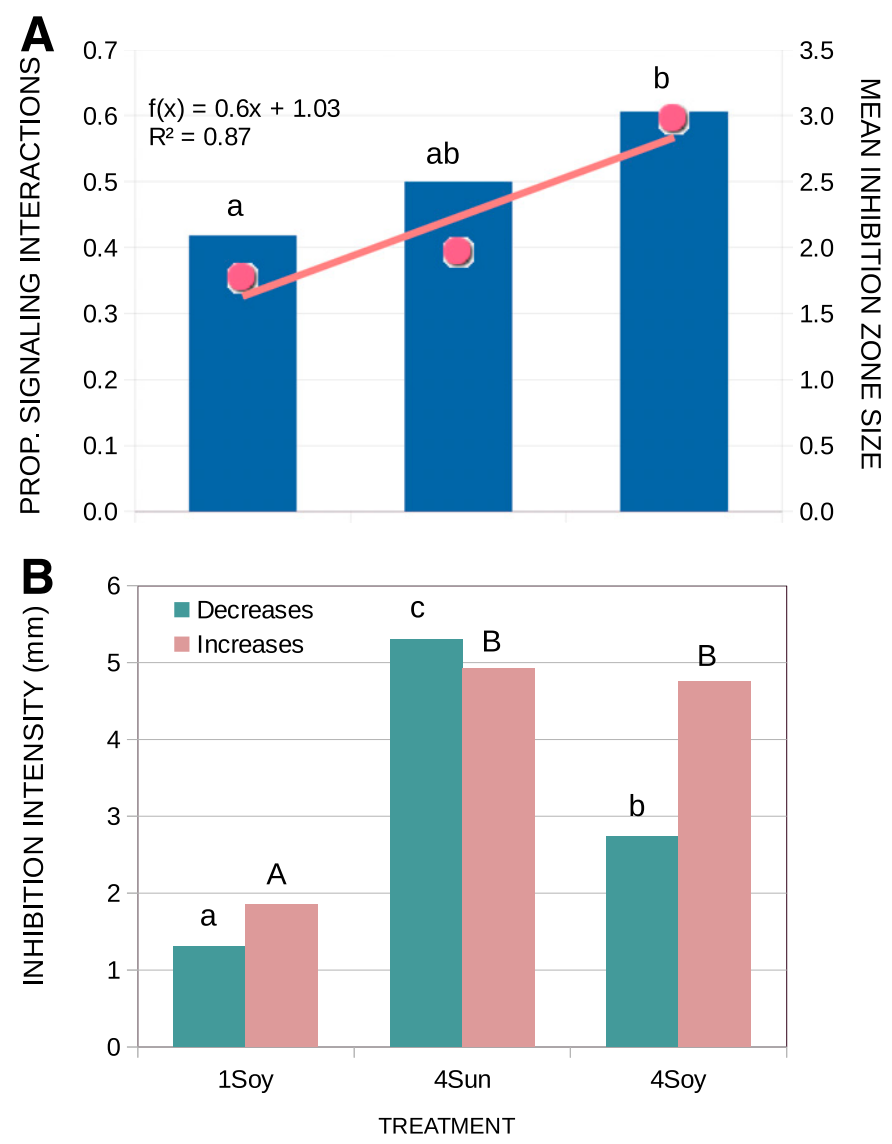

Fig. 5. The three communities tested varied in the frequency of signaling interactions. A, The community from plot 1 Soy differed significantly from plot 4 Soy in the frequency of inhibition-shifting interactions (Chi-square $[1, n=152]=5.249, P=0.02$ ), while the community from plot 4 Sun did not vary significantly from any. In addition, the proportion of signaling interactions was higher in communities with higher inhibition intensity (mean inhibition zone sizes) of the whole community $(f(x)=0.33 \ln (x)+$ $\left.0.25 ; r^{2}=0.94\right)$. B, The intensity of signaling varied significantly among communities. On average, isolates from soils of the 4-year rotations (4Sun, 4Soy) had larger shifts in inhibition than isolates from the soil of the 1 -year rotation (1Soy). rotations had six different species in this time period, while the 1and 2-year rotations had two and four species, respectively. Similar densities of bacteria and Streptomyces in 3- and 4-year rotations likely reflect the cumulative influences of temporal plant diversity on microbial populations in soil. The noncropped sites, which were occupied by a mixture of perennial plant species, had intermediate densities of bacteria and Streptomyces, but plant species diversity in these soils varies in space rather than time. Bacterial and Streptomyces densities also varied with plant host. Over all samples, soils planted to maize showed larger bacterial and Streptomyces populations, while soils planted to soybean had significantly smaller bacterial population densities than other plant species. It should be taken into account, that in this experiment, when trying to compare soils with different crops, different rotation length is sometimes a confounding factor. Nonetheless, soils planted to maize harbored significantly higher densities of bacteria and Streptomyces than soils from the same rotation at different stages (maize versus soybean or sorghum). Furthermore, bacterial densities were higher in soils planted to maize than in all stages of the 4-year rotation, which when combined were not significantly different from the soils from the 3-year rotation. These results suggest that strategies to vary the identity and rotational diversity within cropping systems can provide the potential to build the desired high-density soil microbial communities.

Pathogen suppressive activity was also significantly influenced by soil history. Previous work suggested two possible mechanisms by which plants and plant diversity might influence pathogensuppressive populations. One model proposes that microbial interactions are the primary factor imposing selection for pathogensuppressive populations (Kinkel et al. 2011). Specifically, the model hypothesizes that plants that support high densities of soil microbes will result in selection for more competitive microbial populations, and thus higher densities and frequencies of antagonistic Streptomyces (Davelos et al. 2004; Pérez et al. 2007). In our work, the significant positive correlations between the density of inhibitory Streptomyces and total bacterial densities, as well as between the inhibitory intensity of Streptomyces and bacterial densities, provide some support for this model. However, although a positive correlation was found between density and proportion of inhibitors in the Streptomyces community, not all soils that had high bacterial densities had high densities of inhibitory Streptomyces. A second model suggests that plant diversity, by generating a diversity of soil carbon substrates for microbial growth, will significantly influence selection for suppressive populations (Kinkel et al. 2011, 2012). Specifically, greater diversity of plant hosts, coupled with a higher diversity of carbon substrates, is hypothesized to provide the opportunity for soil microbes to undergo niche differentiation rather than an antibiotic arms race in response to competition. However, in contrast to previous work showing that monocultures support more pathogen-suppressive populations than 16-species polycultures (Bakker et al. 2010; Craig MacLean et al. 2004; Essarioui et al. 2017), in this work plots having the greatest number of different plant species (six species) over the preceding 4-year period had significantly higher densities of pathogen-suppressive Streptomyces than plots with four species. Plots with only two species over the same period supported intermediate densities of pathogen-suppressive Streptomyces. Thus, in this work, low-diversity and high-diversity plant rotational sequences both had higher pathogen-suppressive capacities than intermediate density rotations. However, in the absence of rigorous measurements of soil carbon diversity in relation to plant host or plant diversity over time, disentangling the complex and likely interactive effects of plant species, rotation length, and plant diversity on soil chemistry and the pathogen-suppressive capacities of Streptomyces in the phytobiome remains elusive.

Overall, both soil nitrogen and organic matter varied among cropping systems, and were significantly correlated with bacterial 
and Streptomyces densities. Previous research documents the sensitivity of bacterial and Streptomyces populations to soil management and nitrogen content (Jiménez-Bueno et al. 2016; Navarrete et al. 2015; Pii et al. 2016). Soil chemical properties were also related to pathogen suppressive populations. High nitrate, organic matter and potassium were positively correlated with greater zones of inhibition, suggesting these properties may be associated with more suppressive communities. Previous work has shown that soils undergoing longterm enrichment with single carbon sources have Streptomyces populations with greater inhibitory capacities (Schlatter et al. 2009). However, though both this previous study and our current work suggest that high nutrient content in soils may promote inhibitory communities, variation in the diversity of nutrients deposited in soil via plant roots exudates may constrain simple relationships between nutrient availability and pathogen suppression in field settings (Bakker et al. 2012; Kinkel et al. 2012; Salles et al. 2004). Further analysis of the relationships between the quantity and the quality of soil carbon or organic matter in relation to pathogen-suppressive capacity is needed to draw rigorous conclusions about the factors that mediate pathogen-suppressive populations of Streptomyces in soil.

Microbial competitive interactions are perceived to be central to selection for pathogen-suppressive phenotypes among Streptomyces, yet the factors the mediate those phenotypes in vivo are poorly understood. In particular, it is well known that signaling and other interactions that alter inhibitory capacities of individual populations may contribute significantly to pathogen suppression capacity (Vaz Jauri and Kinkel 2014). Interspecies signaling that modifies inhibition among Streptomyces has been shown to vary among populations from natural prairie communities (Vaz Jauri and Kinkel 2014), but has been little studied in agricultural settings. In this work, we show that shifts in inhibition in response to another population were common in these agricultural soils. Streptomyces populations from soils with different cropping histories varied in their capacities to alter the inhibitory phenotypes of coexisting populations, supporting the hypothesis that signaling may vary in roles and relevance among communities. Overall, the frequency of sympatric interactions that shifted inhibitory phenotypes was higher in the agricultural soil communities studied in this work than in the native prairie soil communities described previously (Vaz Jauri and Kinkel 2014) and higher than that in other studies characterizing allopatric interactions (Slattery et al. 2001). Furthermore, the intensity of changes in inhibitory phenotypes in response to another Streptomyces varied significantly among plots and was greatest in soils from longer rotations. These soils, from the longer rotations, also had higher bacterial, Streptomyces, and inhibitors densities than the soil from the 1-year rotation. In addition, within the two communities from soils of longer rotations, some interactions induced inhibitory phenotypes in isolates that were not inhibitory when grown alone. Furthermore, the frequency of inhibitionshifting interactions increased with the average intensity of inhibition within the community. It may be that crop management practices such as longer rotation periods, which increase microbial densities, contribute to maintenance of a higher frequency of interspecies signaling. Populations within high-density and highly inhibitory communities may obtain greater fitness benefits than populations in low-density communities from modulating their antibiotic phenotypes in response to others. However, though our results show significant differences in phenotype-shifting interactions among Streptomyces from different cropping systems, and the potential for significant consequences for the phytobiome, we lack statistical power for drawing clear conclusions about the effects of particular cropping systems on signaling dynamics.

Native microbiota-driven plant protection offers a compelling yet elusive (but hopefully not illusive) goal for plant disease management.
Although unlikely to achieve complete protection against every pathogen, management of soil microbiomes offers the hope of reducing pathogen inoculum, disease, and crop losses due to plant pathogens on many crops. However, achieving consistently healthy phytobiomes via management of soil microbiomes will require deep understanding of the ways in which management factors, including plant host, crop rotation, and soil nutrients, interact to influence pathogen suppressive populations in soil. At present, we lack such understanding. In this work, we document significant differences in densities of pathogen-suppressive Streptomyces populations across diverse long-term cropping systems. Pathogen suppressive population densities were positively correlated with bacterial densities as well as with soil nitrate and organic matter, and Streptomyces from low-diversity and high-diversity rotational sequences were more inhibitory than those from intermediate diversity rotations. Further studies are needed to determine the direct versus indirect roles of plant host, rotation length, and plant diversity on pathogen-suppressive populations in soil, and to identify the prospects for direct management of soil nutrients to achieve consistent enhancements in suppressive populations. Finally, this work points to variation in interspecies signaling among soil communities as a potentially significant and unexplored factor in understanding both the evolution and practical effectiveness of disease-suppressive capacities in the phytobiome.

\section{LITERATURE CITED}

Alguacil, M., Torrecillas, E., Torres, P., García-Orenes, F., and Roldán, A. 2012. Longterm effects of irrigation with waste water on soil AM fungi diversity and microbial activities: The implications for agro-ecosystem resilience. PLoS One 7:1-7.

Allan, E., Manning, P., Alt, F., Binkenstein, J., Blaser, S., Blüthgen, N., Böhm, S., Grassein, F., Hölzel, N., Klaus, V. H., Kleinebecker, T., Morris, E. K., Oelmann, Y., Prati, D., Renner, S. C., Rilling, M. C., Schaefer, M., Schloter, M., Schmitt, B., Schöning, I., Schrumpf, M., Solly, E., Sorkau, E., Steckel, J., Steffen-Dewenter, I., Stempfhuber, B., Tschapka, M., Weiner, C. N., Weisser, W. W., Werner, M., Westphal, C., Wilcke, W., and Fischer, M. 2015. Land use intensification alters ecosystem multifunctionality via loss of biodiversity and changes to functional composition. Ecol. Lett. 18:834-843.

Andrew, D. R., Fitak, R. R., Munguia-Vega, A., Racolta, A., Martinson, V. G., and Dontsova, K. 2012. Abiotic factors shape microbial diversity in Sonoran Desert soils. Appl. Environ. Microbiol. 78:7527-7537.

Araújo da Silva, K. R., Salles, J. F., Seldin, L., and van Elsas, J. D. 2003. Application of a novel Paenibacillus-specific PCR-DGGE method and sequence analysis to assess the diversity of Paenibacillus spp. in the maize rhizosphere. J. Microbiol. Methods 54:213-231.

Azziz, G., Bajsa, N., Haghjou, T., Taulé, C., Valverde, Á., Igual, J. M., and Arias, A. 2012. Abundance, diversity and prospecting of culturable phosphate solubilizing bacteria on soils under crop-pasture rotations in a no-tillage regime in Uruguay. Appl. Soil Ecol. 61:320-326.

Bailey, K. 2009. Pest control: Fungi, streptomycetes and yeasts. In: Agricultural Sciences, volume II. Eolss Publishing, Oxford, UK.

Bakker, M. G., Glover, J. D., Mai, J. G., and Kinkel, L. L. 2010. Plant community effects on the diversity and pathogen suppressive activity of soil streptomycetes. Appl. Soil Ecol. 46:35-42.

Bakker, M. G., Manter, D. K., Sheflin, A. M., Weir, T. L., and Vivanco, J. M. 2012. Harnessing the rhizosphere microbiome through plant breeding and agricultural management. Plant Soil 360:1-13.

Becker, D. M., and Kinkel, L. L. 1999. Strategies for quantitative isolation of Streptomyces from soil for studies of pathogen ecology and disease control. Recent Res. Dev. Microbiol. 3:349-362.

Becker, D. M., Kinkel, L. L., and Janet, L. 1997. Evidence for interspecies communication and its potential role in pathogen suppression in a naturally occurring disease suppressive soil1. Can. J. Plant Pathol. 990:1399-1404.

Bibb, M. J. 2005. Regulation of secondary metabolism in streptomycetes. Curr. Opin. Microbiol. 8:208-215.

Birkhofer, K., Schöning, I., Alt, F., Herold, N., Klarner, B., Maraun, M., et al. 2012. General relationships between abiotic soil properties and soil biota across spatial scales and different land-use types. PLoS One 7:e43292.

Bressan, W. 2003. Biological control of maize seed pathogenic fungi by use of actinomycetes. BioControl 48:233-240. 
Bunet, R., Mendes, M. V., Rouhier, N., Pang, X., Hotel, L., Leblond, P., et al. 2008. Regulation of the synthesis of the angucyclinone antibiotic alpomycin in Streptomyces ambofaciens by the autoregulator receptor AlpZ and its specific ligand. J. Bacteriol. 190:3293-3305.

Ceja-Navarro, J. A., Rivera-Orduña, F. N., Patiño-Zúñiga, L., Vila-Sanjurjo, A., Crossa, J., Govaerts, B., and Dendooven, L. 2010. Phylogenetic and multivariate analyses to determine the effects of different tillage and residue management practices on soil bacterial communities. Appl. Environ. Microbiol. 76:3685-3691.

Chandler, J. R., Heilmann, S., Mittler, J. E., and Greenberg, E. P. 2012. Acylhomoserine lactone-dependent eavesdropping promotes competition in a laboratory co-culture model. ISME J. 6:2219-2228.

Cook, R. J. 2007. Take-all decline: Model system in the science of biological control and clue to the success of intensive cropping. Pages 399-430 in: Biological Control a Global Perspective: Case Studies from Around the World. C. Vincent, M. Goettel, and G. Lazarovits, eds. CABI Publishing, Wallingford, UK.

Craig MacLean, R., Dickson, A., and Bell, G. 2004. Resource competition and adaptive radiation in a microbial microcosm. Ecol. Lett. 8:38-46.

Cretoiu, M. S., Korthals, G. W., Visser, J. H. M., and van Elsas, J. D. 2013. Chitin amendment increases soil suppressiveness toward plant pathogens and modulates the actinobacterial and oxalobacteraceal communities in an experimental agricultural field. Appl. Environ. Microbiol. 79:5291.

Cugudda, L., and Garibaldi, A. 1981. Soil suppressive to Fusarium wilt of carnation: Studies on mechanism of suppressiveness. Acta Hortic. 216:67-76.

D’Alia, D., Nieselt, K., Steigele, S., Müller, J., Verburg, I., and Takano, E. 2010. Noncoding RNA of glutamine synthetase I modulates antibiotic production in Streptomyces coelicolor A3(2). J. Bacteriol. 192:1160-1164.

Davelos, A. L., Xiao, K., Flor, J. M., and Kinkel, L. L. 2004. Genetic and phenotypic traits of streptomycetes used to characterize antibiotic activities of field-collected microbes. Can. J. Plant Pathol. 89:79-89.

Di Rienzo, J. A., Csanoves, F., Balzarini, M. G., Gonzalez, L., Tablada, M., and Robledo, C. 2011. InfoStat versión 2011. Grup. InfoStat, FCA, Univ. Nac. Córdoba, Argentina. 8:195-199.

Essarioui, A., LeBlanc, N., Kistler, H. C., and Kinkel, L. L. 2017. Plant community richness mediates inhibitory interactions and resource competition between Streptomyces and Fusarium populations in the rhizosphere. Microbiol. Ecol. 74:157-167.

Garbeva, P., and van Veen, J. 2004. Microbial diversity in soil: Selection microbial populations by plant and soil type and implications for disease suppressiveness. Annu. Rev. Phytopathol. 42:243-270.

Gordon, T. R., and Leveau, J. H. J. 2010. Plant pathology: A story about biology. Annu. Rev. Phytopathol. 48:293-309.

Gottelt, M., Hesketh, A., Bunet, R., Puri, P., and Takano, E. 2012. Characterisation of a natural variant of the $\gamma$-butyrolactone signaling receptor. BMC Res. Notes 5:379.

Hjort, K., Bergström, M., Adesina, M. F., Jansson, J. K., Smalla, K., and Sjöling, S. 2010. Chitinase genes revealed and compared in bacterial isolates, DNA extracts and a metagenomic library from a phytopathogen-suppressive soil. FEMS Microbiol. Ecol. 71:197-207.

Hosni, T., Moretti, C., Devescovi, G., Suarez-Moreno, Z. R., Fatmi, M. B., Guarnaccia, C., et al. 2011. Sharing of quorum-sensing signals and role of interspecies communities in a bacterial plant disease. ISME J. 5:1857-1870.

Janmaat, A. F. 2007. Development of resistance to the biopesticide Bacillus thuringiensis kurstaki. Pages 195-200 in: Biological Control: A Global Perspective. C. Vincent, ed. CABI Publishing, Wallingford, UK.

Jiménez-Bueno, N. G., Valenzuela-Encinas, C., Marsch, R., Ortiz-Gutiérrez, D., Verhulst, N., Govaerts, B., et al. 2016. Bacterial indicator taxa in soils under different long-term agricultural management. J. Appl. Microbiol. 120:921-933.

Jones, J. C., Koziel, M. G., and Uknes, S. J. 2016. Modified biological control agents and their uses. Patent Pub. No. US 2016/0353745 A1.

Keel, C., Schnider, U., Maurhofer, M., Voisard, C., Laville, J., Burger, U., et al. 1992. Suppression of root disseases by Pseudomonas fluorescens CHA0: Importance of the bacterial secondary metabolite 2,4-diacetylphloroglucinol. Mol. Plant-Microbe Interact. 5:4-13.

Keel, C., Weller, D. M., Natsch, A., Défago, G., Cook, R. J., and Thomashow, L. S. 1996. Conservation of the 2,4-diacetylphloroglucinol biosynthesis locus among fluorescent Pseudomonas strains from diverse geographic locations. Appl. Environ. Microbiol. 62:552-563.

Keller, L., and Surette, M. G. 2006. Communication in bacteria: An ecological and evolutionary perspective. Nat. Rev. Microbiol. 4:249-258.

Kinkel, L. L., Bakker, M. G., and Schlatter, D. C. 2011. A coevolutionary framework for managing disease-suppressive soils. Annu. Rev. Phytopathol. 49:47-67.

Kinkel, L. L., Schlatter, D. C., Bakker, M. G., and Arenz, B. E. 2012. Streptomyces competition and co-evolution in relation to plant disease suppression. Res. Microbiol. 163:490-499.
Landa, B. B., Mavrodi, O. V., Raaijmakers, J. M., Gardener, B. B. M Thomashow, L. S., and Weller, D. M. 2002. Differential ability of genotypes of 2,4-diacetylphloroglucinol-producing Pseudomonas fluorescens strains to colonize the roots of pea plants. Appl. Environ. Microbiol. 68:3226-3237.

Larkin, R. P., Griffin, T. S., and Honeycutt, C. W. 2010. Rotation and cover crop effects on soilborne potato diseases, tuber yield, and soil microbial communities. Plant Dis. 94:1491-1502.

Larkin, R. P., Hopkins, D. L., and Martin, F. N. 1996. Suppression of Fusarium wilt of watermelon by nonpathogenic Fusarium oxysporum and other microorganisms recovered from a disease-suppressive soil. Phytopathology 86:812-819.

Lauber, C. L., Strickland, M. S., Bradford, M., and Fierer, N. 2008. The influence of soil properties on the structure of bacterial and fungal communities across land-use types. Soil Biol. Biochem. 40:2407-2415.

Lew, S., Lew, M., Biedunkiewicz, A., and Szarek, J. 2012. Impact of pesticide contamination on aquatic microorganism populations in the littoral zone. Arch. Environ. Contam. Toxicol. 64:399-409.

Liu, D., Anderson, N. A., and Kinkel, L. L. 1995. Biological control of potato scab in the field with antagonistic Streptomyces scabies. Phytopathology 85: 827-831.

Liu, G., Chater, K. F., Chandra, G., Niu, G., and Tan, H. 2013. Molecular regulation of antibiotic biosynthesis in Streptomyces. Microbiol. Mol. Biol. Rev. 77:112-143.

Lumsden, R. D., and Knauss, J. F. 2007. Commercial development of Trichoderma virens for damping-off disease. Pages 219-225 in: Biological Control: A Global Perspective. CABI Publishing, Wallingford, UK.

Mandeel, Q., and Baker, R. 1991. Mechanisms involved in biological control of Fusarium wilt of cucumber with strains of nonpathogenic Fusarium oxysporum. Phytopathology 81:462-469.

Mazzola, M. 2007. Manipulation of rhizosphere bacterial communities to induce suppressive soils. J. Nematol. 39:213-220.

Mendes, R., Kruijt, M., de Bruijn, I., Dekkers, E., van der Voort, M., Schneider, J. H. M., et al. 2011. Deciphering the rhizosphere microbiome for diseasesuppressive bacteria. Science 332:1097-1100.

Millard, W. A., and Taylor, C. B. 1927. Antagonism of micro-organisms as the controlling factor in the inhibition of scab by green-manuring. Ann. Appl. Biol. 14:202-216

Navarrete, A. A., Tsai, S. M., Mendes, L. W., Faust, K., de Hollander, M., Cassman, N. A., et al. 2015. Soil microbiome responses to the short-term effects of Amazonian deforestation. Mol. Ecol. 24:2433-2448.

O'Rourke, S., Wietzorrek, A., Fowler, K., Corre, C., Challis, G. L., and Chater, K. F. 2009. Extracellular signalling, translational control, two repressors and an activator all contribute to the regulation of methylenomycin production in Streptomyces coelicolor. Mol. Microbiol. 71:763-778.

Panuwet, P., Siriwong, W., Prapamontol, T., Ryan, P. B., Fiedler, N., Robson, M. G., et al. 2012. Agricultural pesticide management in Thailand: Status and population health risk. Environ. Sci. Policy 17:72-81.

Pérez, C., Dill-Macky, R., and Kinkel, L. L. 2007. Management of soil microbial communities to enhance populations of Fusarium graminearum-antagonists in soil. Plant Soil 302:53-69.

Perneel, M., D’hondt, L., De Maeyer, K., Adiobo, A., Rabaey, K., and Höfte, M. 2008. Phenazines and biosurfactants interact in the biological control of soilborne diseases caused by Pythium spp. Environ. Microbiol. 10:778-788.

Pii, Y., Borruso, L., Brusetti, L., Crecchio, C., Cesco, S., and Mimmo, T. 2016. The interaction between iron nutrition, plant species and soil type shapes the rhizosphere microbiome. Plant Physiol. Biochem. 99:39-48.

Platero, R., James, E. K., Rios, C., Iriarte, A., Sandes, L., Zabaleta, M., et al. 2016. Novel Cupriavidus strains isolated from root nodules of native Uruguayan Mimosa species. Appl. Environ. Microbiol. 82:3150-3164.

Pulsawat, N., Kitani, S., Fukushima, E., and Nihira, T. 2009. Hierarchical control of virginiamycin production in Streptomyces virginiae by three pathwayspecific regulators: VmsS, VmsT and VmsR. Microbiology 155:1250-1259.

Rosenzweig, N., Tiedje, J. M., Quensen, J. F. I., Meng, Q., and Hao, J. J. 2012. Microbial communities associated with potato common scab-suppressive soil determined by pyrosequencing analyses. Plant Dis. 96:718-725.

Ryan, P. R., Dessaux, Y., Thomashow, L. S., and Weller, D. M. 2009. Rhizosphere engineering and management for sustainable agriculture. Plant Soil 321:363-383.

Sakuma, F., Maeda, M., Takahashi, M., Hashizume, K., and Kondo, N. 2011. Suppression of common scab of potato caused by Streptomyces turgidiscabies using lopsided oat green manure. Plant Dis. 95:1124-1130.

Salles, J. F., van Veen, J. A., and van Elsas, J. D. 2004. Multivariate analyses of Burkholderia species in soil: Effect of crop and land use history. Appl. Environ. Microbiol. 70:4012-4020. 
Schlatter, D., Fubuh, A., Xiao, K., Hernandez, D., Hobbie, S., and Kinkel, L. 2009. Resource amendments influence density and competitive phenotypes of Streptomyces in soil. Microbiol. Ecol. 57:413-420.

Schmalenberger, A., and Tebbe, C. C. 2002. Bacterial community composition in the rhizosphere of a transgenic, herbicide-resistant maize (Zea mays) and comparison to its non-transgenic cultivar Bosphore. FEMS Microbiol. Ecol. 40:29-37.

Shange, R. S., Ankumah, R. O., Ibekwe, A. M., Zabawa, R., and Dowd, S. E. 2012. Distinct soil bacterial communities revealed under a diversely managed agroecosystem. PLoS One 7:e40338.

Shirling, E. B., and Gottlieb, D. 1966. Methods for characterization of Streptomyces species. Int. J. Syst. Bacteriol. 16:313-340.

Slattery, M., Rajbhandari, I., and Wesson, K. 2001. Competition-mediated antibiotic induction in the marine bacterium Streptomyces tenjimariensis. Microbiol. Ecol. 41:90-96.

Tamm, L., Thürig, B., Bruns, C., Fuchs, J. G., Köpke, U., Laustela, M., et al. 2010. Soil type, management history, and soil amendments influence the development of soil-borne (Rhizoctonia solani, Pythium ultimum) and airborne (Phytophthora infestans, Hyaloperonospora parasitica) diseases. Eur. J. Plant Pathol. 127:465-481.

Taulé, C., Zabaleta, M., Mareque, C., Platero, R., Sanjurjo, L., Sicardi, M., et al. 2012. New betaproteobacterial Rhizobium strains able to efficiently nodulate Parapiptadenia rigida (Benth.). Brenan. Appl. Environ. Microbiol. 78:1692-1700.

van Bruggen, A. H. C., Gamliel, A., and Finckh, M. R. 2015. Plant disease management in organic farming systems. Pest Manag. Sci. doi.org/10.1002/ps.4145

van Loon, L. C., Bakker, P. A., and Pieterse, C. M. 1998. Systemic resistance induced by rhizosphere bacteria. Annu. Rev. Phytopathol. 36:453-483.
Vaz Jauri, P., Altier, N., and Kinkel, L. L. 2016. Streptomyces for sustainability. Pages 251-276 in: Microbial Models: From Environmental to Industrial Sustainability. S. Castro-Sowinski, ed. Springer Singapore, Singapore.

Vaz Jauri, P., and Kinkel, L. L. 2014. Nutrient overlap, genetic relatedness and spatial origin influence interaction-mediated shifts in inhibitory phenotype among Streptomyces spp. FEMS Microbiol. Ecol. 90:264-275.

Veresoglou, S. D., Thornton, B., Menexes, G., Mamolos, A. P., and Veresoglou, D. S. 2012. Soil fertilization leads to a decline in between-samples variability of microbial community $\delta 13 \mathrm{C}$ profiles in a grassland fertilization experiment. PLoS One 7:e44203.

Wiggins, B. E., and Kinkel, L. L. 2005a. Green manures and crop sequences influence alfalfa root rot and pathogen inhibitory activity among soil-borne streptomycetes. Plant Soil 268:271-283.

Wiggins, B. E., and Kinkel, L. L. 2005b. Green manures and crop sequences influence potato diseases and pathogen inhibitory activity of indigenous streptomycetes. Phytopathology 95:178-185.

Xu, Z., Wang, Y., Chater, K. F., Ou, H.-Y., Xu, H. H., Deng, Z., et al. 2017. Large-scale transposition mutagenesis of Streptomyces coelicolor identifies hundreds of genes influencing antibiotic biosynthesis. Appl. Environ. Microbiol. 83:e02889-16.

Xuan, D. T., Guong, V. T., Rosling, A., Alström, S., Chai, B., and Högberg, N. 2011. Different crop rotation systems as drivers of change in soil bacterial community structure and yield of rice, Oryza sativa. Biol. Fertil. Soils 48: 217-225.

Zhu, H., Sandiford, S. K., and van Wezel, G. P. 2014. Triggers and cues that activate antibiotic production by actinomycetes. J. Ind. Microbiol. Biotechnol. 41:371-386. 